\title{
Warning Time Analysis of Nasiri River Flash Flood due to Several Possible Natural Dam Break Events
}

\author{
Andry Putra Styawan \\ River Basin Organization Kalimantan I, West Kalimantan, Pontianak, INDONESIA \\ andry_sty@yahoo.com \\ Adam Pamudji Rahardjo \\ Department of Civil and Environmental Engineering, Universitas Gadjah Mada, Yogyakarta, INDONESIA \\ adam.pamudji.r@gmail.com \\ Joko Sujono \\ Department of Civil and Environmental Engineering, Universitas Gadjah Mada, Yogyakarta, INDONESIA \\ jsujono@ugm.ac.id
}

\begin{abstract}
Flash flood disasters caused by natural dam break have already occurred several times in Indonesia which contributes so much life loss and material damage. This research was aimed to study threat level on flash food disasters on the possibility of the locations where the natural dam was formed by the landslide on the river cliffs at the watershed. The flash flood in Nasiri River on August $1^{\text {st }}, 2012$ would be used for the model in this research. Therefore, hydrology and hydraulic simulations would be conducted on the process of natural dam break at specified altitudes which were predicted to occur in five locations along the Nasiri River. Several big rain event data sets that could occur on specified years from the previous studies would be used to obtain rain event with the hydrological model. Natural dam break was modeled with HEC-HMS 4.1. The hydraulic simulation used the dynamic flow model in the HEC-RAS 5.3 software. The natural dam collapse would be approached by considering the event that has existed around the study location, and also the local geological condition. The result showed that for all the natural dam break scenarios, it could be concluded that the storage filling time was in the time range of 2 hours 26 minutes up to 5 minutes. The flood travel time was ranged from 27 minutes to 2 minutes. The available warning time was quite short, which was less than 3 hours; therefore the need of early warning system's facilities and infrastructure are absolutely necessary as one of mitigation effort for flash flood disaster in Nasiri Village.
\end{abstract}

Keywords: natural dam, dam break, flash flood.

\section{INTRODUCTION}

Nasiri Village is a village in Huamual Sub-district, Western Seram Regency, Maluku Province; it is precisely located in western part of the Seram Island peninsula. Most of the Nasiri Village inhabitants live in the alluvial fan area, because of its hilly topography and the steep slopes on most of its land. This type of topography is very vulnerable to natural disaster, particularly flash flood and landslides.

To reduce the disaster risk, physical and non-physical efforts are needed in the places where the flash flood disasters are prone to happen. Physical efforts are such as building reservoir, check dam, and levee; as for nonphysical effort is such as early warning system, which has a very important role and also relatively easier to attempt. In the effort to reduce flash flood disaster risk, the time interval available between the early warning given and the event where flash flood hit the residential area determines the success level of the disaster risk mitigation. On the event of a flash flood caused by natural dam break, the interval comes from the time between forming of the natural dam and its collapse and also a time of flood propagation from the location of the natural dam to the area that threatened by flash flood. It could also be added the time interval between the heavy rain peaks that are preceded by previous rain up to the forming of the natural dam; however the peak of the flood which would cause the forming of the natural dam is hard to identify.

The time of filling the reservoir is an important determinant for the available time interval for the early warning and evacuation, as it generally is longer from the flood propagation time interval. The reservoir capacity and the volume of water that would fill it are the main parameters in the time interval calculation. Therefore, it is necessary to understand the knowledge on a combination between the abovementioned volumes, which is determined by the topography of the river slope, height, and location of the natural dam, rainfall characteristic and the area size of rain catchment area for each natural dam locations. 
The objective of this research was to obtain the relation between the height of the natural dam that is likely to collapse, the filling time of the natural dam storage, and the discharge of the flood peak from the natural dam break. Special objectives of this research are as follows, to determine the flood discharge value if natural dam break occurs on a certain location, and to estimate the flood arrival time as one of the parameters of the early warning system.

\section{LITERATURE REVIEW}

\subsection{Flood Routing}

The water flow on the irregular channel and high resistance have much-changing wave configuration. The ways to determine the flood flow modification is known as flood routing (Chow, 1997). In hydrologic engineering, flood routing is an important technique needed to obtain a complete solution for flood controlling and flood forecasting problem. To fulfill this necessity, flood routing is considered as a needed procedure to determine hydrograph of a certain point in downstream from the known hydrograph of a certain point in upstream.

According to Sanjay and Ravindra (2012), the flood routing model could be classified hydraulically as follows:

a) Simplified hydraulic model. This model uses the conservation of mass equation and also a simple form of momentum conservation equation.

b) Complete hydraulic model.

This model that used complete St. Venant equation is also known as complete hydraulic or dynamic wave model. HEC-RAS is one of the complete hydraulic models that able to simulate the calculation of one-dimensional water level profile for unsteady flow on the channel, channel network, one main river, or river with tributaries.

\subsection{Model of Dam Break}

In the hydraulic model, dam break could be assumed as spillway gate with the height width of the spillway crest changes from small to certain size, or as the water gate hole that gradually opens (Styawan, 2017). The first assumption is close to the case of natural dam break by overtopping, while the second assumption is close to the case of natural dam break by piping. At the time the spillway or the gate changed, routing is conducted (flood routing calculation).

With above approaches, there are several dam break parameters that would influence the hydrograph which generated exactly on the downstream. For the break by overtopping, the dam break aperture is assumed to be trapezoid shaped with a base width smaller than the top width. In modeling as in Figure 1, the break of the slope of the trapezoidal side of break opening is assumed to be stable with the symbol of $z$, the base width is $b$, and depth of the aperture is $h_{d}$, which starts from initial number until the determined maximum limit. This aperture growth could be assumed as linear to time, or follow certain curve according to the possibilities that could happen on location. The speed of the aperture opening and its duration, $\tau$ greatly determines the flood peak discharge caused by the break. The distance between the bottom of the valley on the dam and the base of the aperture opening hole is by the symbol of $h_{b}$. The value of this parameter decreases to a certain minimum limit of $\mathrm{h}_{\mathrm{bm}}$. The recommended parameters of dam break are shown in Table 1.

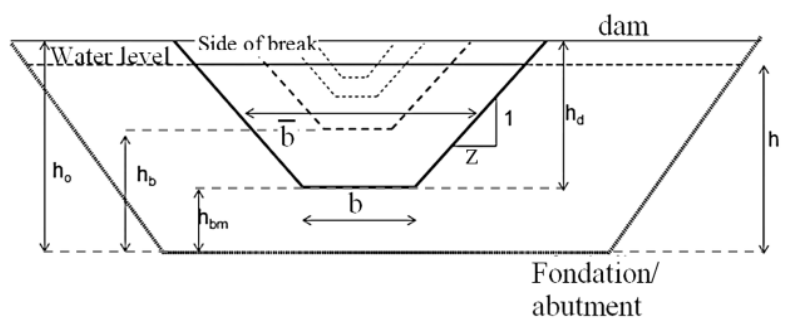

Figure 1. Model of dam break process (Rahardjo, et al., 2009)

According to Rachmadan, et al. (Rachmadan, et al., 2014), before the dam suffered a total break, it is first preceded by breaching. Breaching is an aperture that formed in the body of the dam at break occurred. The mechanism of the break is actually not so well understood, both for the concrete dam and earth-fill dam. To forecast flood on the downstream that caused by dam break, it is commonly assumed that the dam was totally and suddenly break.

Table 1. Parameters of dam break (Anon., 1991)

\begin{tabular}{llll}
\hline & $\begin{array}{l}\text { Earth fill } \\
\text { dam }\end{array}$ & $\begin{array}{l}\text { Concrete } \\
\text { dam }\end{array}$ & Arch dam \\
\hline $\begin{array}{l}\text { Breaching } \\
\text { width }\end{array}$ & $\begin{array}{l}0.5 \text { to } 4 \mathrm{x} \\
\text { dam } \\
\text { height }\end{array}$ & $\begin{array}{l}\text { several times } \\
\text { monolith } \\
\text { width }\end{array}$ & $\begin{array}{l}\text { dam total } \\
\text { weight }\end{array}$ \\
\hline $\begin{array}{l}\text { Side slope of } \\
\text { breaching }\end{array}$ & 0 to 1 & 0 & $\begin{array}{l}\text { the slope } \\
\text { of the } \\
\text { valley }\end{array}$ \\
\hline $\begin{array}{l}\text { Break time } \\
\text { (hour) }\end{array}$ & 0.5 to 4 & 0.1 to 0.5 & $\begin{array}{l}\text { close to } \\
\text { sudden } \\
\text { (0.1 hour) }\end{array}$ \\
\hline $\begin{array}{l}\text { Water level } \\
\text { elevation at } \\
\text { break }\end{array}$ & $\begin{array}{l}1 \text { to } 5 \text { feet } \\
\text { above } \\
\text { dam peak }\end{array}$ & $\begin{array}{l}10 \text { to } 50 \text { feet } \\
\text { above dam } \\
\text { peak }\end{array}$ & $\begin{array}{l}10 \text { to } 50 \\
\text { feet above } \\
\text { dam peak }\end{array}$ \\
\hline
\end{tabular}




\section{RESEARCH METHOD}

\subsection{Research Location}

The research location was limited only to be in the Nasiri, Luhu Village, Huamual Sub-district, and Western Seram Regency of Maluku Province, as shown in Figure 2.

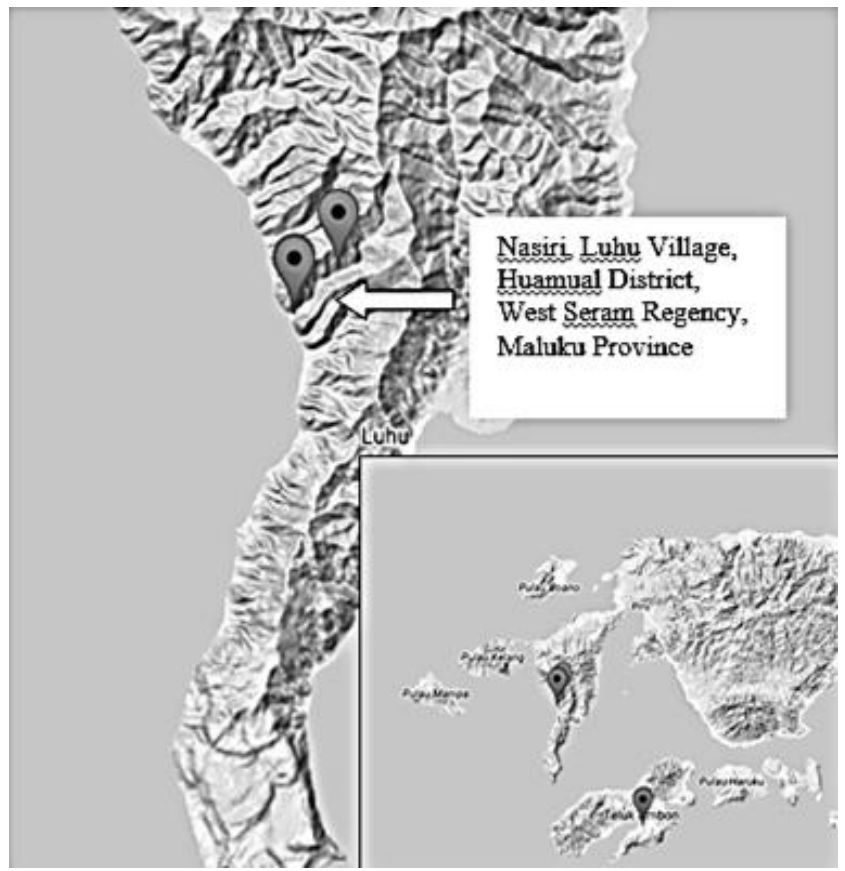

Figure 2. Research Location

\subsection{Research Procedure}

In this research, the observed natural dam was formed by the landslide that closes the river flow, therefore created a natural storage without reviewing the geological aspects. The observed natural dam break was only with 1 pattern, which was caused by the overtopping. The avalanche material was considered to be strong enough to hold the water storage volume until the water storage elevation exceeded the peak elevation of the dam. The simulation used 4 types of rain series, which were the rain event at flash flood on August $1^{\text {st }}$, 2012, and rainfall with a return period of 5, 3, and 2 years. The effect of rainfall volume on the downstream of the natural break to the flood event in Nasiri residential area was not observed.

This research used the data collected in previous research by Musthofa (2015). The data required was the Digital Surface model of research location, the river channel data, rainfall data, and field condition data in the form of photographs which will be used to consider several of the values of hydrologic and hydraulic parameters required in modeling.

\subsection{Digital Surface Model}

The division of Nasiri Sub-watershed was detailed by using $50 \mathrm{~m}$ contour which was processed from the DEM SRTM data. This division result is shown in Figure 3. The length and area of the main rivers on each sub-watershed were then calculated. The area and length of the rivers for each Nasiri Sub-watershed is shown in Table 2.

Table 2. The area and length of the rivers for each subwatershed

\begin{tabular}{lll}
\hline $\begin{array}{l}\text { Sub- } \\
\text { watershed }\end{array}$ & Area $\left(\mathrm{km}^{2}\right)$ & River length $(\mathrm{km})$ \\
\hline 1 & 1.300 & 1.474 \\
2 & 3.755 & 2.604 \\
3 & 5.463 & 3.766 \\
4 & 8.100 & 5.700 \\
5 & 8.377 & 6.311 \\
\hline
\end{tabular}

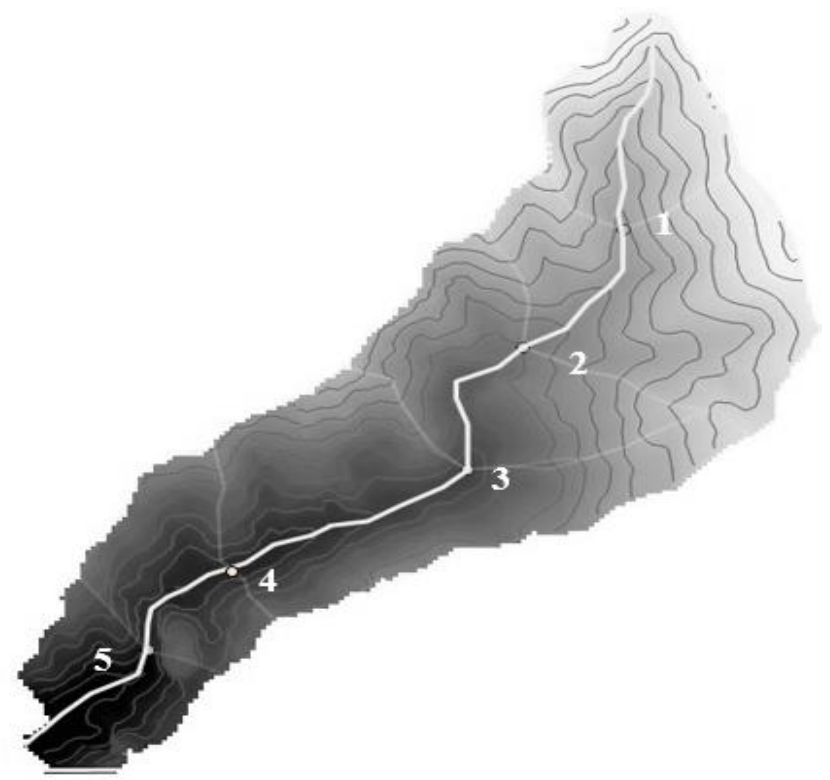

Figure 3. The division of sub-watershed based on $50 \mathrm{~m}$ contour

\subsection{Watershed Parameter}

The obtained information on physical characteristic of the watershed is shown in Table 3 (Mustofa, 2014).

Table 3. Physical characteristic of Nasiri Watershed (Mustofa, 2014)

\begin{tabular}{ll}
\hline Parameter & Value \\
\hline Watershed area $(A)$ & $9.332 \mathrm{~km}^{2}$ \\
River length $(L)$ & $6.387 \mathrm{~km}$ \\
Basic slope of river $(S)$ & 0.113 \\
Drainage density $(D)$ & 3.51 \\
Source frequency $(S N)$ & 0.53 \\
\hline
\end{tabular}




\subsection{Rainfall Data}

Rainfall data of Nasiri station was used to make rainfall distribution pattern in Nasiri Watershed. While the rainfall data used for the natural dam break modeling was the rain event occurred at flash flood disaster in Nasiri River on August 1 $1^{\text {st, }} 2012$ at the Lohiatala rain station, and also the design rainfall with a return period of 5, 3, and 2 years at Pattimura Station, as shown in Table 4. The location of hydrology station in Nasiri Watershed is shown in Figure 4.

Table 4. Rainfall data for dam break modeling (Mustofa, 2014)

\begin{tabular}{lll}
\hline Return period & Rain Station & Volume $(\mathrm{mm} /$ day $)$ \\
\hline August $1^{\text {st, } 2012}$ & Sta. Lohiatala & 225.2 \\
5 years & Sta. Pattimura & 213.6 \\
3 years & Sta. Pattimura & 177.4 \\
2 years & Sta. Pattimura & 144.8 \\
\hline
\end{tabular}

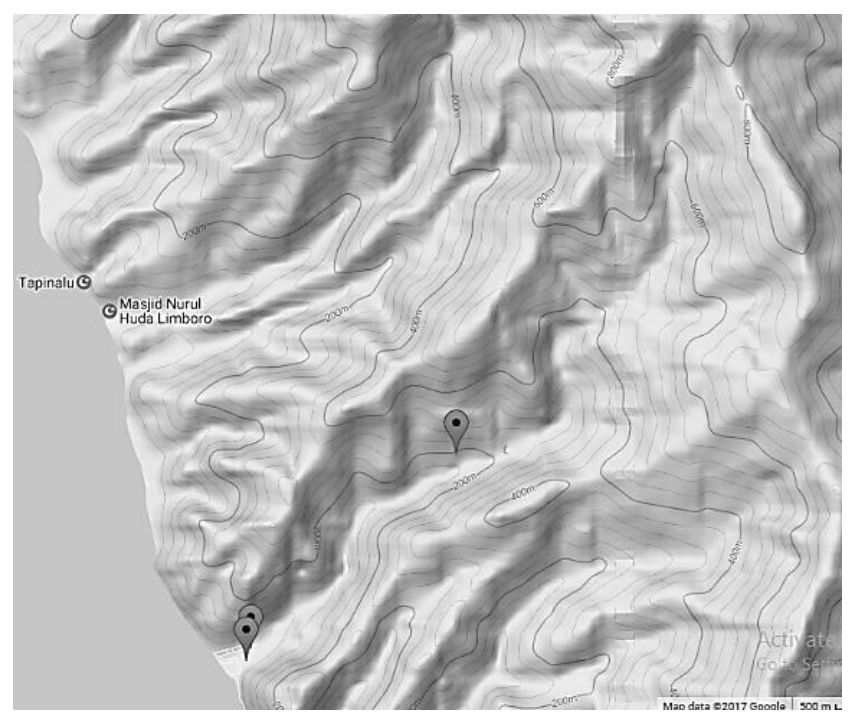

Figure 4. Location of hydrology station in Nasiri Watershed

\subsection{Hydrology modeling with HEC-HMS 4.1}

Hydrology simulation was conducted with HEC-HMS 4.1 software, in order to find hydrograph of the direct runoff which would fill the natural dam storage. The simulation was conducted for each scenario of five different sub-watersheds. In which each sub-watershed scenarios were being distinguished by several natural dam height elevation and variation of design rainfall that was used. The natural dam break modeling also used the HEC-HMS software.

\subsection{Flow Hydraulic Modelling with HEC-RAS 5.3}

Various hydraulic modeling has been carried out by applying the HEC-RAS Software (Chandrabose \& Nair
B, 2014). In this research, the application of HEC-RAS 5.3 is aimed of the followings.

a) Modelling the cross section and long section of the river which the flood discharge passed through the residential area,

b) Conducting flood routing in order to find the hydrograph of the flood that reached the residential area,

c) To find the discharge and elevation of flood water level that reached the residential area.

\section{RESULTS AND DISCUSSIONS}

\subsection{Rain}

The data from rain station in Nasiri was used to determine the rainfall distribution pattern. There were at least 79 rain events in the time range of April 2016 (equipment started to work) until December 2016. From all of the rain events, high-intensity rain then took; which was rainfall with volume more than 50 $\mathrm{mm} /$ day and or have the depth of 0.25 per minute. Rain events that filled the criteria were presented in cumulative distribution, as shown in Figure 5 as follows.

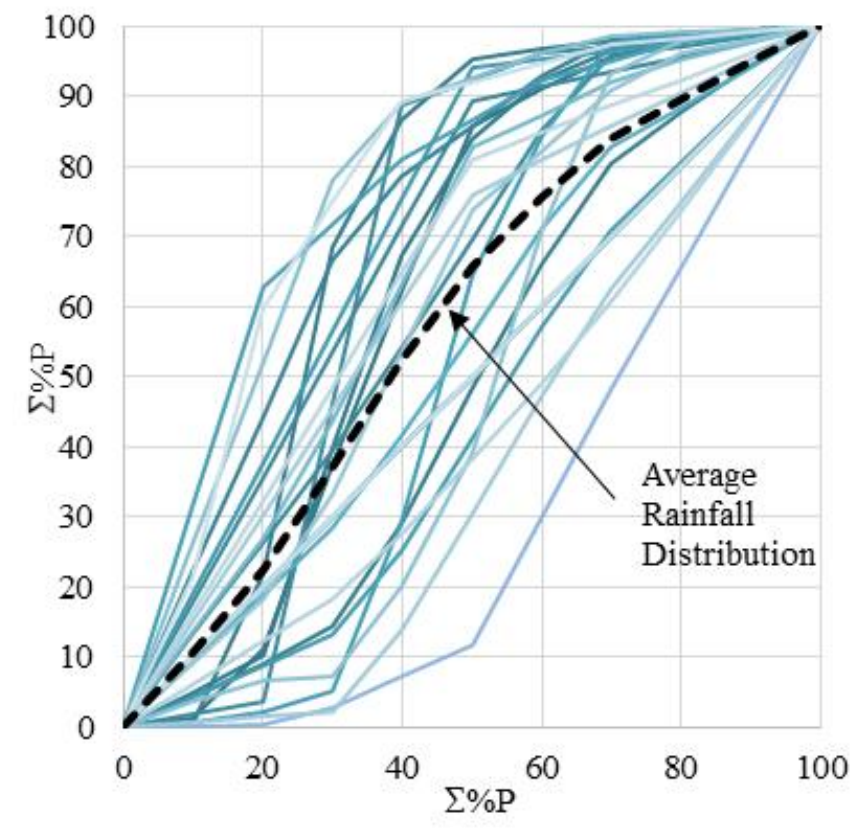

Figure 5. Rainfall distribution of Nasiri Watershed

From the result of the model calibration-verification, the rainfall distribution probability that was the closest to the event in the field was the $50 \%$ probability. This distribution pattern was then used to distribute rain

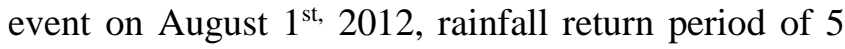
years, 3 years, and 2 years, as shown in Figure 6. 

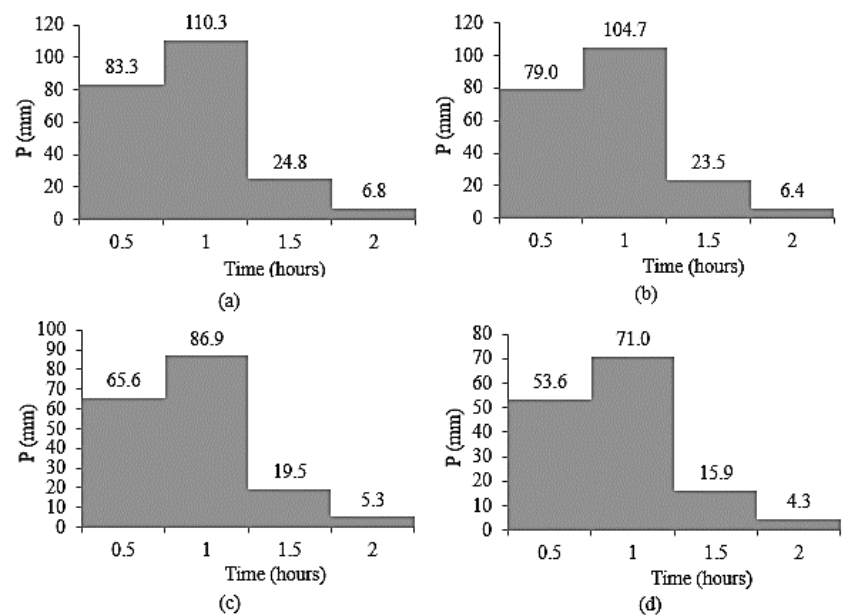

Figure 6. Rainfall distribution pattern for event of $1^{\text {st }}$ August 2012 (a) return period of 5 years (b) return period of 3 years (c) return period of 2 years $(d)$

\subsection{Loss/Abstraction}

The Loss value was searched by using the SCS-CN method, with utilizing the rainfall data $(P)$-flow $(Q)$. The curve number value is shown in Table 5.

Table 5. Curve number value

\begin{tabular}{ll}
\hline Soil Condition & Curve Number $(\mathrm{CN})$ \\
\hline Normal Condition (CN II) & 85.48 \\
Wet Condition $(\mathrm{CN}$ III) & 93.10 \\
\hline
\end{tabular}

\subsection{Transform-Nakayasu Synthetic Unit Hydrograph}

The Nakayasu Synthetic Unit Hydrograph was made for each sub-watershed, which is shown in Figure 7.

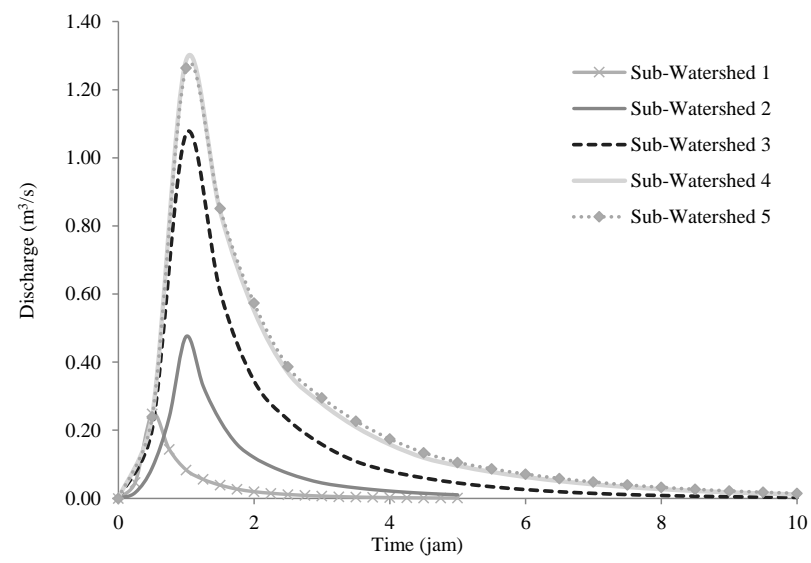

Figure 7. Nakayasu Synthetic Unit Hydrograph for each sub-watershed

\subsection{Base Flow}

The Base Flow value was obtained by direct observation on the field. The base flow value on Nasiri River was $\pm 0.25 \mathrm{~m}^{3} / \mathrm{s}$.

\subsection{Calculation of Natural Dam Storage Volume}

By utilizing the Digital Elevation Model data, the inundation area size and the natural dam storage volume for each sub-watershed scenarios with a various elevation of natural dam height could be calculated. The results from the natural dam storage volume calculation are shown in Figure 8 to Figure 12.

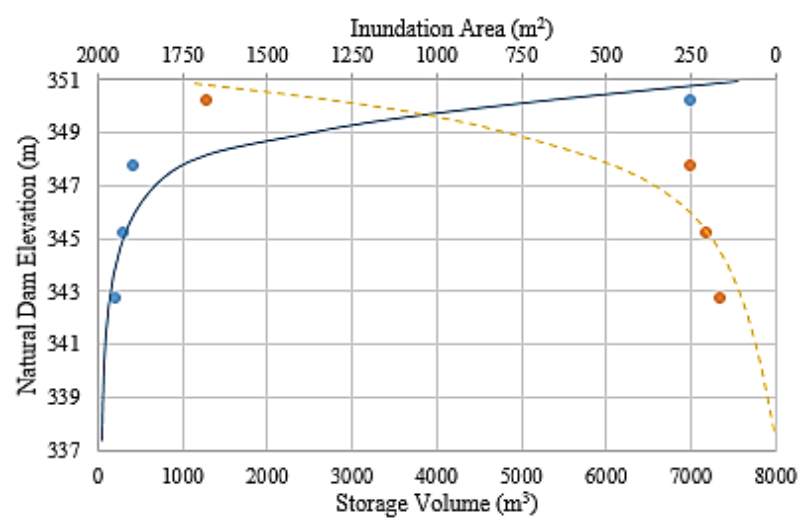

Figure 8. Characteristic of Sub-watershed 1 natural dam storage

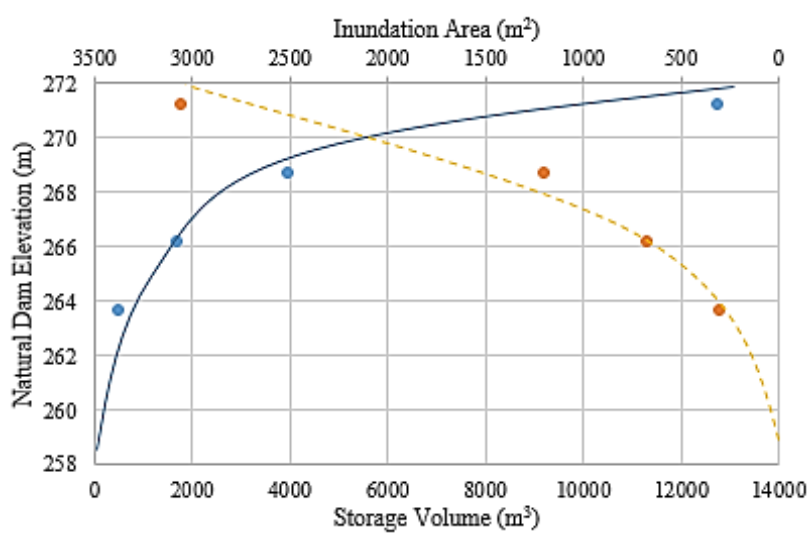

Figure 9. Characteristic of Sub-watershed 2 natural dam storage

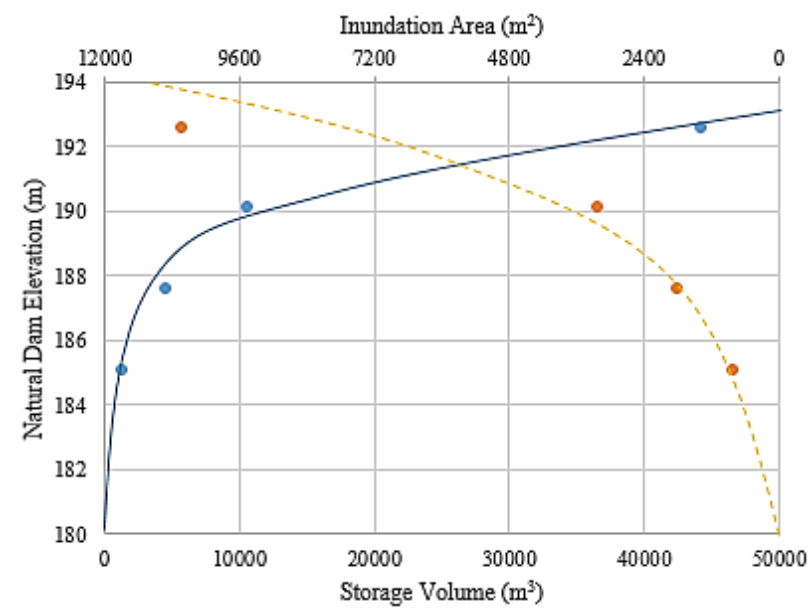

Figure 10. Characteristic of Sub-watershed 3 natural dam storage 


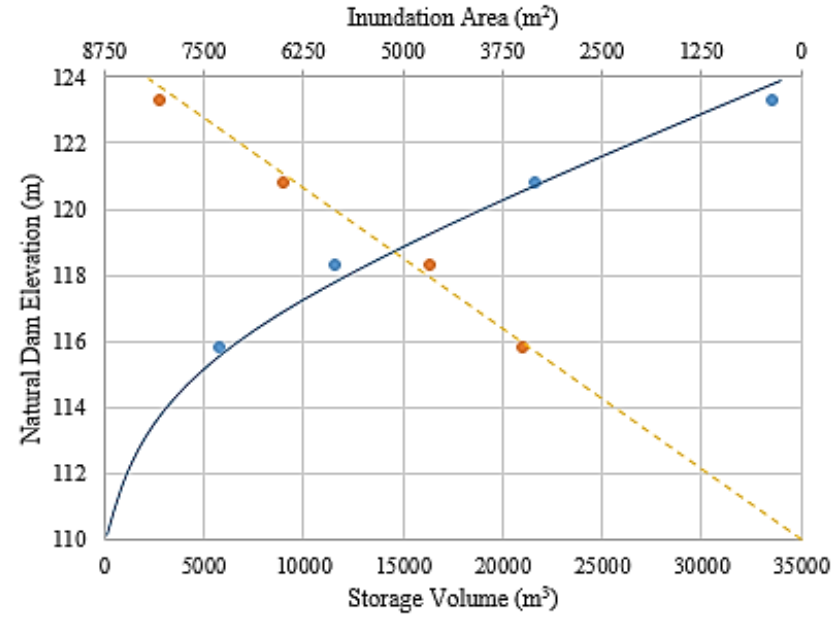

Figure 11. Characteristic of Sub-watershed 4 natural dam storage

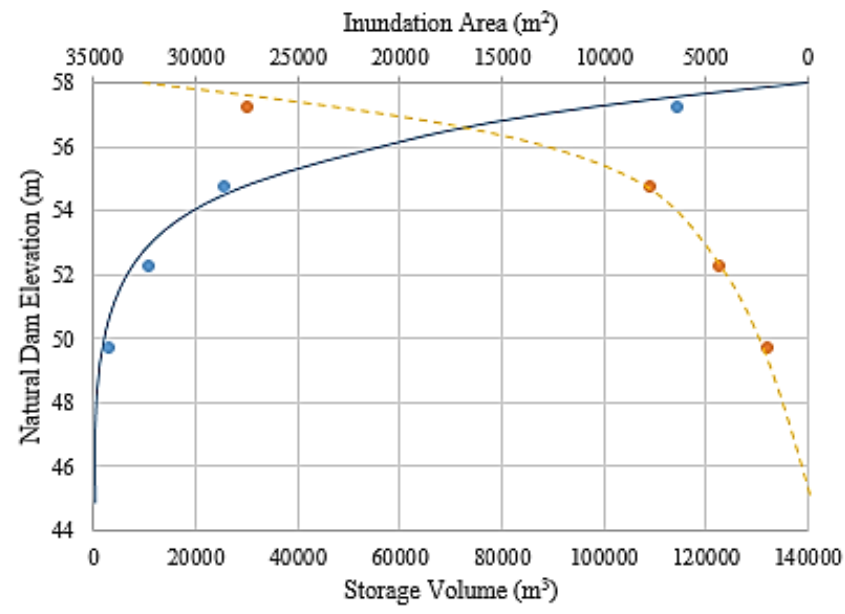

Figure 12. Characteristic of Sub-watershed 5 natural dam storage

\subsection{Result of Hydrology Analysis}

The result from hydrology model simulation for sub-watershed 3 could be seen in Figure 13. Figure 14 shows outflow hydrograph resulted from running the dam break scenario for natural dam elevation of $12.5 \mathrm{~m}$ at sub-watershed 3 .

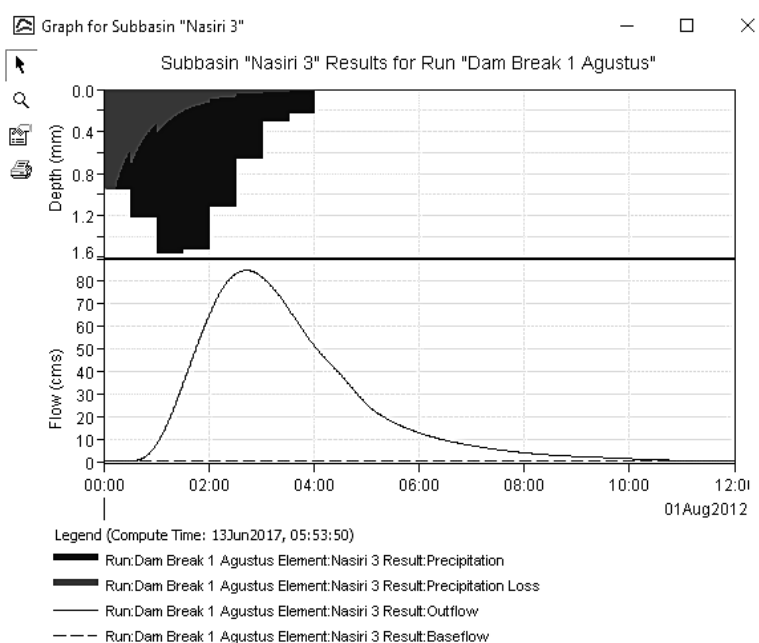

(a) Rain event on August $1^{\text {st, }} 2012$

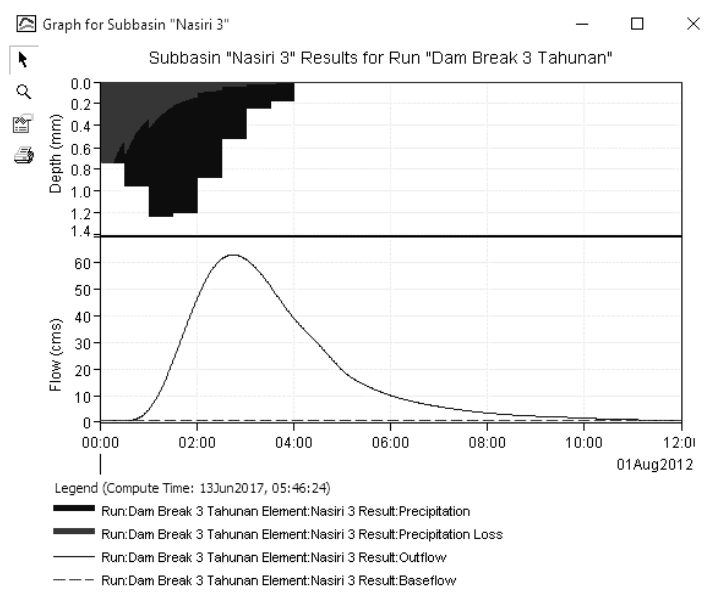

(c) Rainfall return period of 3 years

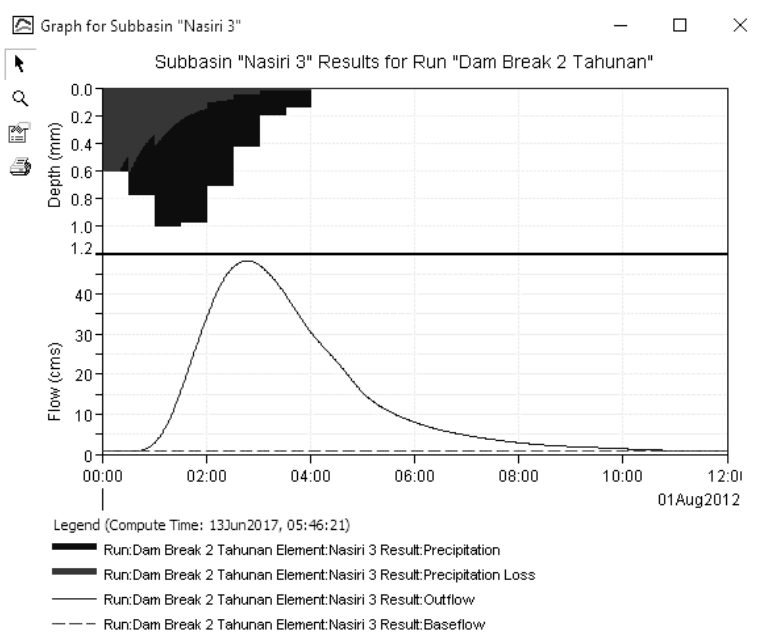

(b) Rainfall return period of 2 years

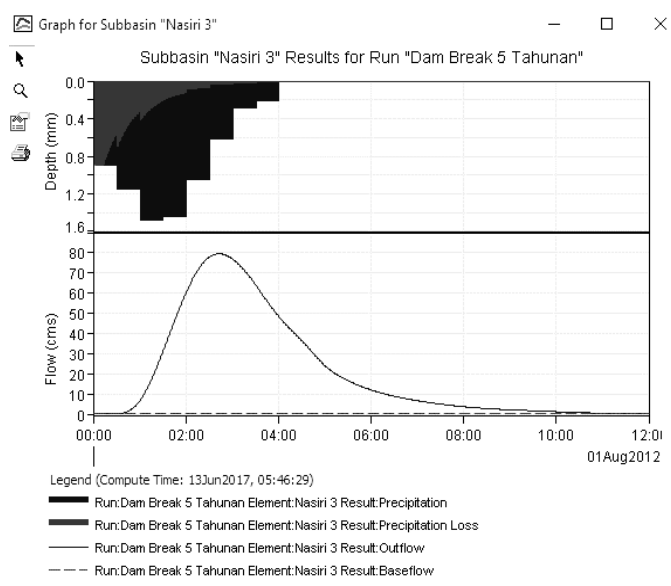

(d) Rainfall return period of 5 years

Figure 13. Running result of the hydrology model for sub-watershed 3 


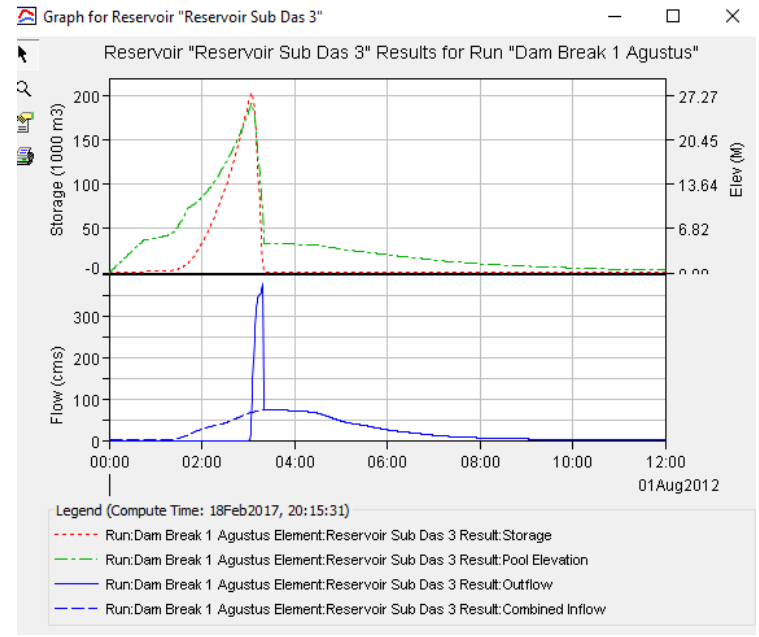

(a) Rain event on August $1^{\text {st, }} 2012$

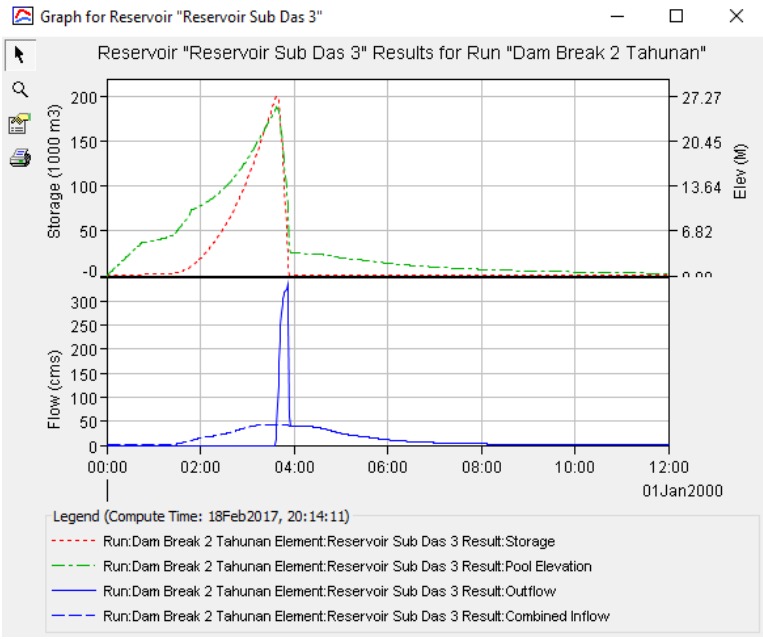

(b) Rainfall return period of 2 years

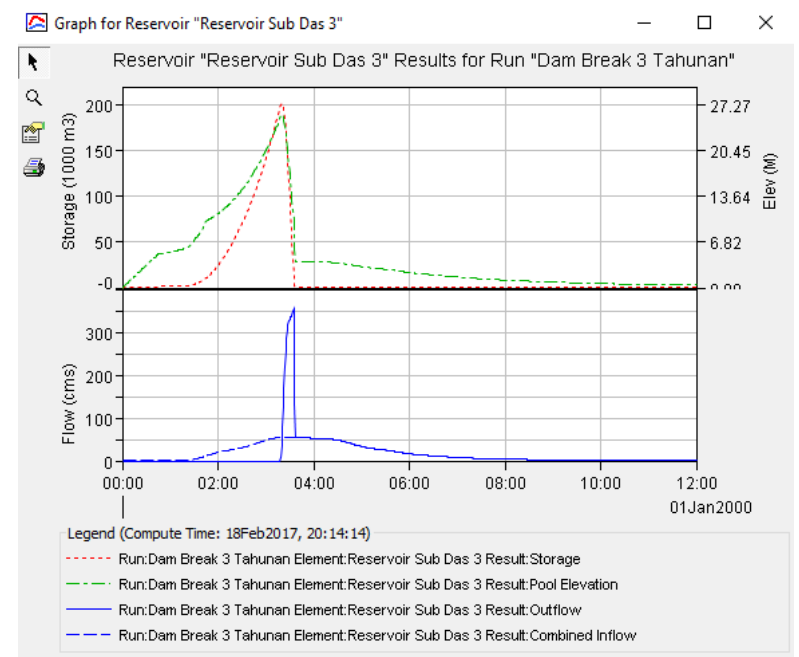

(c) Rainfall return period of 3 years

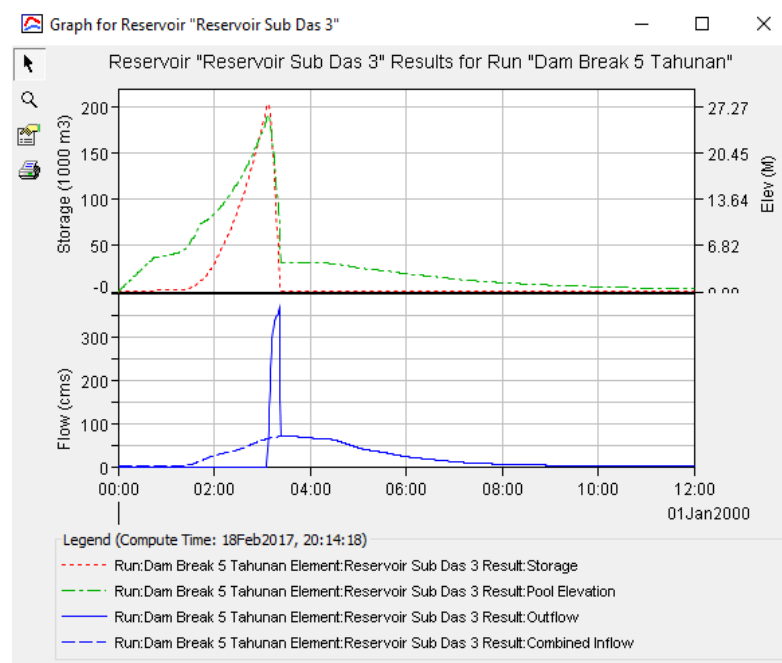

(d) Rainfall return period of 5 years

Figure 14. Outflow hydrograph for natural dam elevation of $12.5 \mathrm{~m}$ at sub-watershed 3 .

Recapitulation of the calculation for storage filling time of the natural dam could be seen in Table 6 to Table 9 as follows.

Table 6. Storage filling time for natural dam sub-watershed 1 and 2.

\begin{tabular}{|c|c|c|c|c|c|c|c|c|}
\hline \multirow{3}{*}{$\begin{array}{l}\text { Watershed } \\
\text { elevation }(\mathrm{m})\end{array}$} & \multicolumn{8}{|c|}{ Storage filling time natural watershed (Hour: Minute) } \\
\hline & \multicolumn{4}{|c|}{ Sub-watershed 1} & \multicolumn{4}{|c|}{ Sub-watershed 2} \\
\hline & Rain event & 2 years & 3 years & 5 years & Rain event & 2 years & 3 years & 5 years \\
\hline 12.5 & $1: 05$ & $1: 21$ & $1: 13$ & $1: 07$ & $1: 25$ & $1: 42$ & $1: 34$ & $1: 27$ \\
\hline 10 & $0: 11$ & $0: 11$ & $0: 11$ & $0: 11$ & $1: 01$ & $1: 12$ & 1:07 & 1:03 \\
\hline 7.5 & 0:07 & 0:07 & 0:07 & 0:07 & $0: 38$ & $0: 40$ & $0: 39$ & $0: 39$ \\
\hline 5 & 0:05 & 0:05 & $0: 05$ & $0: 05$ & $0: 12$ & $0: 12$ & $0: 12$ & $0: 12$ \\
\hline
\end{tabular}

Table 7. Storage filling time for natural dam sub-watershed 3, 4, and 5.

\begin{tabular}{|c|c|c|c|c|c|c|c|c|c|c|c|c|}
\hline \multirow{3}{*}{$\begin{array}{l}\text { Watershed } \\
\text { elevation } \\
\text { (m) }\end{array}$} & \multicolumn{12}{|c|}{ Storage filling time natural watershed (Hour: Minute) } \\
\hline & \multicolumn{4}{|c|}{ Sub-watershed 3} & \multicolumn{4}{|c|}{ Sub-watershed 4} & \multicolumn{4}{|c|}{ Sub-watershed 5} \\
\hline & $\begin{array}{l}\text { Rain } \\
\text { event }\end{array}$ & $\begin{array}{l}2 \\
\text { years }\end{array}$ & $\begin{array}{l}3 \\
\text { years }\end{array}$ & $\begin{array}{l}5 \\
\text { years }\end{array}$ & $\begin{array}{l}\text { Rain } \\
\text { event }\end{array}$ & $\begin{array}{l}2 \\
\text { years }\end{array}$ & $\begin{array}{l}3 \\
\text { years }\end{array}$ & $\begin{array}{l}5 \\
\text { years }\end{array}$ & $\begin{array}{l}\text { Rain } \\
\text { event }\end{array}$ & $\begin{array}{l}2 \\
\text { years }\end{array}$ & $\begin{array}{l}3 \\
\text { years }\end{array}$ & $\begin{array}{l}5 \\
\text { years }\end{array}$ \\
\hline 12.5 & $1: 30$ & $1: 49$ & $1: 40$ & $1: 32$ & $1: 58$ & $2: 26$ & $2: 12$ & $2: 01$ & $1: 49$ & $2: 14$ & $2: 01$ & $1: 52$ \\
\hline 10 & $1: 06$ & $1: 20$ & $1: 13$ & 1:07 & $1: 45$ & 2:08 & $1: 57$ & $1: 47$ & $1: 17$ & $1: 33$ & $1: 25$ & $1: 19$ \\
\hline 7.5 & $0: 54$ & $1: 05$ & $0: 59$ & $0: 55$ & $1: 32$ & $1: 52$ & $1: 42$ & $1: 34$ & 1:04 & $1: 18$ & $1: 11$ & 1:06 \\
\hline 5 & $0: 32$ & $0: 33$ & $0: 33$ & $0: 32$ & $1: 20$ & $1: 37$ & $1: 28$ & $1: 22$ & $0: 48$ & $0: 58$ & $0: 53$ & $0: 49$ \\
\hline
\end{tabular}


Table 8 . Break time of natural dam sub-watershed 1 and 2.

\begin{tabular}{|c|c|c|c|c|c|c|c|c|}
\hline \multirow{3}{*}{$\begin{array}{l}\text { Watershed } \\
\text { elevation }(\mathrm{m})\end{array}$} & \multicolumn{8}{|c|}{ Break Time (Hour: Minute) } \\
\hline & \multicolumn{4}{|c|}{ Sub-watershed 1} & \multicolumn{4}{|c|}{ Sub-watershed 2} \\
\hline & Rain event & $\begin{array}{l}2 \\
\text { years }\end{array}$ & $\begin{array}{l}3 \\
\text { years }\end{array}$ & 5 years & Rain event & $\begin{array}{l}2 \\
\text { years }\end{array}$ & $\begin{array}{l}3 \\
\text { years }\end{array}$ & 5 years \\
\hline 12.5 & $0: 39$ & $0: 44$ & $0: 42$ & $0: 40$ & $1: 04$ & $1: 15$ & $1: 10$ & $1: 05$ \\
\hline 10 & $0: 36$ & $0: 39$ & $0: 38$ & $0: 37$ & $0: 46$ & $0: 51$ & $0: 49$ & $0: 47$ \\
\hline 7.5 & 0:01 & $0: 01$ & 0:01 & 0:01 & $0: 14$ & $0: 14$ & $0: 14$ & $0: 14$ \\
\hline 5 & 0:01 & $0: 01$ & 0:01 & 0:01 & $0: 14$ & $0: 14$ & $0: 14$ & $0: 14$ \\
\hline
\end{tabular}

Table 9. Break time of natural dam sub-watershed 3, sub-watershed 4, and sub-watershed 5.

\begin{tabular}{|c|c|c|c|c|c|c|c|c|c|c|c|c|}
\hline \multirow{3}{*}{$\begin{array}{l}\text { Watershed } \\
\text { elevation } \\
\text { (m) }\end{array}$} & \multicolumn{12}{|c|}{ Break Time (Hour: Minute) } \\
\hline & \multicolumn{4}{|c|}{ Sub-watershed 3} & \multicolumn{4}{|c|}{ Sub-watershed 4} & \multicolumn{4}{|c|}{ Sub-watershed 5} \\
\hline & $\begin{array}{l}\text { Rain } \\
\text { event }\end{array}$ & $\begin{array}{l}2 \\
\text { years }\end{array}$ & $\begin{array}{l}3 \\
\text { years }\end{array}$ & $\begin{array}{l}5 \\
\text { years }\end{array}$ & $\begin{array}{l}\text { Rain } \\
\text { event }\end{array}$ & $\begin{array}{l}2 \\
\text { years }\end{array}$ & $\begin{array}{l}3 \\
\text { years }\end{array}$ & $\begin{array}{l}5 \\
\text { years }\end{array}$ & $\begin{array}{l}\text { Rain } \\
\text { event }\end{array}$ & $\begin{array}{l}2 \\
\text { years }\end{array}$ & $\begin{array}{l}3 \\
\text { years }\end{array}$ & $\begin{array}{l}5 \\
\text { years }\end{array}$ \\
\hline 12.5 & $1: 01$ & $1: 14$ & $1: 08$ & $1: 03$ & $1: 15$ & $1: 31$ & $1: 23$ & $1: 17$ & $1: 07$ & $1: 20$ & $1: 14$ & $1: 08$ \\
\hline 10 & $1: 03$ & 1:09 & $1: 04$ & $1: 05$ & $1: 08$ & $1: 22$ & $1: 15$ & 1:09 & $1: 15$ & $1: 31$ & $1: 23$ & $1: 17$ \\
\hline 7.5 & $0: 36$ & $0: 37$ & $0: 37$ & $0: 36$ & 1:04 & $1: 17$ & $1: 11$ & 1:06 & $0: 51$ & $1: 00$ & $0: 56$ & $0: 52$ \\
\hline 5 & $0: 19$ & $0: 19$ & $0: 19$ & $0: 19$ & $0: 59$ & $1: 11$ & 1:05 & 1:00 & $0: 40$ & $0: 45$ & $0: 43$ & $0: 41$ \\
\hline
\end{tabular}

From the running result of the model, it was known that the outflow hydrograph for scenario Sub-watershed 1 and Sub-watershed 2 was relatively low. Therefore, flood routing with HEC-RAS was not conducted on these two sub-watersheds. The HEC-RAS modeling to find out the flood discharge, the flood water level elevation, and the flood arrival time was only on Subwatershed 3 up to Sub-watershed 5.

\subsection{Running result of HEC-RAS 5.3}

From the result of running the HEC-RAS, some information output were obtained which are: a) Hydrograph of flood and water level elevation for the reviewed points alongside the river flow for each scenario (based on sub-watersheds, natural dam elevation, and the rainfall return period that was used)

b) Flood arrival time on residential area for each scenario (based on sub-watersheds, natural dam elevation, and the rainfall return period that was used)

Following are the result of a hydraulic model running for the Sub-watershed 3 (El. $12.5 \mathrm{~m}$ ). Figure 15 shows the flood discharge and flood water level elevation on Nasiri residential area (RS 60.8) on rain event on August 1 ${ }^{\text {st, }} 2012$. 


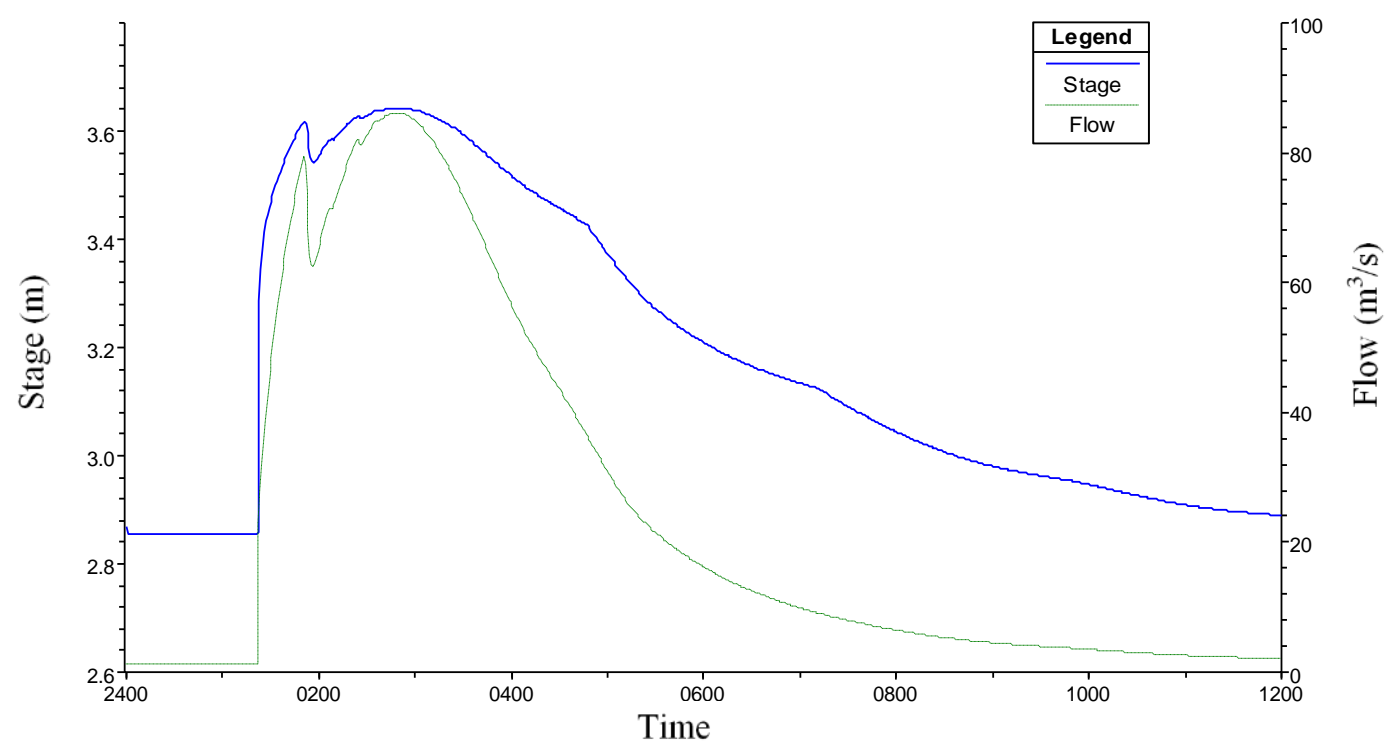

Figure 15. Output of hydraulic model (HEC-RAS) for Sub-watershed 3 (El. 12.5m) on rain event on August $1^{\text {st, }} 2012$

\subsubsection{Peak Discharge and Water Level Elevation}

The following Table 10 and Table 11 shows the peak discharge and water level elevation in Sta. 60,8 (RS 60,8), which was considered able to represent the Nasiri residential area location.

Table 10. Flood-Peak Discharge STA 60.8

\begin{tabular}{|c|c|c|c|c|c|c|c|c|c|c|c|c|}
\hline \multirow{3}{*}{$\begin{array}{l}\text { Watershed } \\
\text { elevation } \\
\text { (m) }\end{array}$} & \multicolumn{12}{|c|}{ Flood-Peak Discharge $\left(\mathrm{m}^{3} / \mathrm{s}\right)$} \\
\hline & \multicolumn{4}{|c|}{ Sub-watershed 3} & \multicolumn{4}{|c|}{ Sub-watershed 4} & \multicolumn{4}{|c|}{ Sub-watershed 5} \\
\hline & $\begin{array}{l}\text { Rain } \\
\text { Event }\end{array}$ & $\begin{array}{l}2 \\
\text { years }\end{array}$ & $\begin{array}{l}3 \\
\text { years }\end{array}$ & $\begin{array}{l}5 \\
\text { years }\end{array}$ & $\begin{array}{l}\text { Rain } \\
\text { Event }\end{array}$ & $\begin{array}{l}2 \\
\text { years }\end{array}$ & $\begin{array}{l}3 \\
\text { years }\end{array}$ & $\begin{array}{l}5 \\
\text { years }\end{array}$ & $\begin{array}{l}\text { Rain } \\
\text { Event }\end{array}$ & $\begin{array}{l}2 \\
\text { years }\end{array}$ & $\begin{array}{l}3 \\
\text { years }\end{array}$ & $\begin{array}{l}5 \\
\text { years }\end{array}$ \\
\hline 12.5 & 86.06 & 61.91 & 69.15 & 80.77 & 142.99 & 108.78 & 121.15 & 137.41 & 164.53 & 141.75 & 151.70 & 159.74 \\
\hline 10 & 86.06 & 49.93 & 64.25 & 80.77 & 128.07 & 84.92 & 101.24 & 121.19 & 127.69 & 95.48 & 108.21 & 123.90 \\
\hline 7.5 & 86.06 & 49.51 & 64.25 & 80.77 & 118.74 & 73.33 & 91.99 & 112.51 & 112 & 64.13 & 83.76 & 105.75 \\
\hline 5 & 86.06 & 49.51 & 64.25 & 80.77 & 113.46 & 69.43 & 87.35 & 107.03 & 112.37 & 64.13 & 83.75 & 105.75 \\
\hline
\end{tabular}

Flood caused by dam break

Flood caused by direct runoff

Table 11. Flood water level elevation STA 60.8

\begin{tabular}{|c|c|c|c|c|c|c|c|c|c|c|c|c|}
\hline \multirow{3}{*}{$\begin{array}{l}\text { Watershed } \\
\text { elevation } \\
\text { (m) }\end{array}$} & \multicolumn{12}{|c|}{ Flood Water Level Elevation (m) } \\
\hline & \multicolumn{4}{|c|}{ Sub-watershed 3} & \multicolumn{4}{|c|}{ Sub-watershed 4} & \multicolumn{4}{|c|}{ Sub-watershed 5} \\
\hline & $\begin{array}{l}\text { Rain } \\
\text { Event }\end{array}$ & $\begin{array}{l}2 \\
\text { years }\end{array}$ & $\begin{array}{l}3 \\
\text { years }\end{array}$ & $\begin{array}{l}5 \\
\text { years }\end{array}$ & $\begin{array}{l}\text { Rain } \\
\text { Event }\end{array}$ & $\begin{array}{l}2 \\
\text { years }\end{array}$ & $\begin{array}{l}3 \\
\text { years }\end{array}$ & $\begin{array}{l}5 \\
\text { years }\end{array}$ & $\begin{array}{l}\text { Rain } \\
\text { Event }\end{array}$ & $\begin{array}{l}2 \\
\text { years }\end{array}$ & $\begin{array}{l}3 \\
\text { years }\end{array}$ & $\begin{array}{l}5 \\
\text { years }\end{array}$ \\
\hline 12.5 & 3.64 & 3.54 & 3.57 & 3.62 & 3.82 & 3.73 & 3.76 & 3.81 & 3.88 & 3.82 & 3.84 & 3.87 \\
\hline 10 & 3.64 & 3.49 & 3.55 & 3.62 & 3.78 & 3.64 & 3.70 & 3.76 & 3.78 & 3.68 & 3.72 & 3.77 \\
\hline 7.5 & 3.64 & 3.48 & 3.55 & 3.62 & 3.75 & 3.59 & 3.66 & 3.74 & 3.74 & 3.55 & 3.63 & 3.71 \\
\hline 5 & 3.64 & 3.48 & 3.55 & 3.62 & 3.74 & 3.58 & 3.65 & 3.72 & 3.74 & 3.55 & 3.63 & 3.71 \\
\hline
\end{tabular}

Flood caused by dam break

Flood caused by direct runoff

The Table 10 shows that the Flood Peak Discharge values were relatively same for the different scenario of dam height. This was because the flood peak discharge occurrence was not affected because of the dam break, but by the mechanism in which the rainfall turns into the flow (direct runoff). Therefore, the presence of natural dam in the location did not affect the flood peak discharge value.
Flood water level elevation compared with the elevation of the existing levee in the location. The levee elevation on STA 60.8 was $5.40 \mathrm{~m}$. This elevation did not exceed by all the conducted running scenario of a dam break.

According to Primahessa (2017), the critical limit that would pose a threat to the Nasiri residential area is the flow with water level elevation of $\pm 1 \mathrm{~m}$. The water 
level elevation with a value that exceeds the critical limit has the potency to trigger the levee on the right and left the side of the river stream to collapse. It was known that the river base elevation on STA 60.8 was $2.675 \mathrm{~m}$. Therefore, the critical limit was water level elevation of $3.675 \mathrm{~m}$. The natural dam break scenarios that caused the critical elevation to be exceeded are shown in bold print.

\subsubsection{Time duration of critical elevation to be reached in Nasiri residential area}

The time duration of critical elevation to be reached in Nasiri residential area was defined as the time duration of critical water level elevation to be reached in Nasiri residential area which was calculated from the event of the natural dam break (Table 12)

\subsubsection{Flood-Peak Time, Arrival Time, and Travel Time}

Flood peak time was the time needed for the flood to reach its peak discharge $\left(Q_{p}\right)$ calculated from the event of a dam break. Travel time was the time needed for the flood peak discharge to reach the Nasiri residential area, which was the result of flood routing. The recapitulation of flood peak time and the flood travel time (hour) are shown in the following Table 13 and Table 14.

The peak time of flood caused by dam break was relatively shorter; this was because there was no influence on the concentration time. The peak time of flood caused by dam break was more affected by the natural discharge volume and the natural dam height. The relatively shorter travel time was caused by the large discharge and the river basic slope that was quite steep, hence creating a quite high flow speed rate.

Table 12. Time duration of critical elevation to be reached in Nasiri residential area STA 60.8

\begin{tabular}{|c|c|c|c|c|c|c|c|c|c|c|c|c|}
\hline \multirow{3}{*}{$\begin{array}{l}\text { Watershed } \\
\text { elevation } \\
\text { (m) }\end{array}$} & \multicolumn{12}{|c|}{ Time duration of critical elevation reached in Nasiri residential area (Hour: Minute) } \\
\hline & \multicolumn{4}{|c|}{ Sub-watershed 3} & \multicolumn{4}{|c|}{ Sub-watershed 4} & \multicolumn{4}{|c|}{ Sub-watershed 5} \\
\hline & $\begin{array}{l}\text { Rain } \\
\text { Event }\end{array}$ & $\begin{array}{l}2 \\
\text { years }\end{array}$ & $\begin{array}{l}3 \\
\text { years }\end{array}$ & $\begin{array}{l}5 \\
\text { years }\end{array}$ & $\begin{array}{l}\text { Rain } \\
\text { Event }\end{array}$ & $\begin{array}{l}2 \\
\text { years }\end{array}$ & $\begin{array}{l}3 \\
\text { years }\end{array}$ & $\begin{array}{l}5 \\
\text { years }\end{array}$ & $\begin{array}{l}\text { Rain } \\
\text { Event }\end{array}$ & $\begin{array}{l}2 \\
\text { years }\end{array}$ & $\begin{array}{l}3 \\
\text { years }\end{array}$ & $\begin{array}{l}5 \\
\text { years }\end{array}$ \\
\hline 12.5 & & & & & $0: 31$ & $0: 34$ & $0: 33$ & $0: 32$ & $0: 26$ & $0: 28$ & $0: 27$ & $0: 27$ \\
\hline 10 & & & & & $0: 43$ & & $0: 57$ & $0: 47$ & $0: 37$ & & $0: 40$ & $0: 37$ \\
\hline 7.5 & & & & & 1:01 & & & 1:04 & $1: 22$ & & & $1: 31$ \\
\hline 5 & & & & & $1: 13$ & & & $1: 19$ & $1: 37$ & & & $1: 43$ \\
\hline
\end{tabular}

Table 13. Flood peak time

\begin{tabular}{|c|c|c|c|c|c|c|c|c|c|c|c|c|}
\hline \multirow{4}{*}{$\begin{array}{l}\text { Watershed } \\
\text { elevation } \\
\text { (m) }\end{array}$} & \multicolumn{12}{|c|}{ Flood peak time $\left(\mathrm{m}^{3} / \mathrm{s}\right)$} \\
\hline & \multicolumn{4}{|c|}{ Sub-watershed 3} & \multicolumn{4}{|c|}{ Sub-watershed 4} & \multicolumn{4}{|c|}{ Sub-watershed 5} \\
\hline & Rain & 2 & 3 & 5 & Rain & 2 & 3 & 5 & Rain & 2 & 3 & 5 \\
\hline & Event & years & years & years & Event & years & years & years & Event & years & years & years \\
\hline 12.5 & $1: 41$ & $0: 41$ & $0: 42$ & $1: 40$ & 1:07 & $0: 47$ & $0: 49$ & $1: 06$ & $0: 39$ & $0: 37$ & $0: 38$ & $0: 38$ \\
\hline 10 & $1: 39$ & $1: 29$ & $1: 29$ & $1: 39$ & $1: 20$ & $0: 54$ & $1: 16$ & $1: 19$ & $0: 46$ & $0: 41$ & $0: 43$ & $0: 46$ \\
\hline 7.5 & 2:06 & 2:09 & 2:08 & 2:07 & $1: 30$ & $1: 07$ & $1: 30$ & $1: 30$ & $1: 59$ & $1: 55$ & $1: 57$ & $1: 59$ \\
\hline 5 & $2: 23$ & $2: 27$ & $2: 26$ & $2: 24$ & $1: 30$ & $1: 30$ & $1: 30$ & $1: 30$ & $2: 10$ & $2: 10$ & $2: 10$ & $2: 10$ \\
\hline
\end{tabular}

Flood caused by dam break

Flood caused by direct runoff

Table 14. Flood travel time

\begin{tabular}{|c|c|c|c|c|c|c|c|c|c|c|c|c|}
\hline \multirow{3}{*}{$\begin{array}{l}\text { Watershed } \\
\text { elevation } \\
\text { (m) }\end{array}$} & \multicolumn{12}{|c|}{ Flood peak time $\left(\mathrm{m}^{3} / \mathrm{s}\right)$} \\
\hline & \multicolumn{4}{|c|}{ Sub-watershed 3} & \multicolumn{4}{|c|}{ Sub-watershed 4} & \multicolumn{4}{|c|}{ Sub-watershed 5} \\
\hline & $\begin{array}{l}\text { Rain } \\
\text { Event }\end{array}$ & $\begin{array}{l}2 \\
\text { years }\end{array}$ & $\begin{array}{l}3 \\
\text { years }\end{array}$ & $\begin{array}{l}5 \\
\text { years }\end{array}$ & $\begin{array}{l}\text { Rain } \\
\text { Event }\end{array}$ & $\begin{array}{l}2 \\
\text { years }\end{array}$ & $\begin{array}{l}3 \\
\text { years }\end{array}$ & 5 years & $\begin{array}{l}\text { Rain } \\
\text { Event }\end{array}$ & $\begin{array}{l}2 \\
\text { years }\end{array}$ & $\begin{array}{l}3 \\
\text { years }\end{array}$ & $\begin{array}{l}5 \\
\text { years }\end{array}$ \\
\hline 12.5 & 0:07 & $0: 07$ & 0:07 & 0:07 & $0: 05$ & $0: 05$ & $0: 05$ & $0: 05$ & $0: 02$ & $0: 02$ & $0: 02$ & $0: 03$ \\
\hline 10 & 0:07 & 0:07 & 0:07 & 0:07 & 0:05 & 0:06 & 0:05 & 0:05 & 0:03 & $0: 03$ & $0: 03$ & 0:03 \\
\hline 7.5 & 0:07 & 0:09 & 0:07 & 0:07 & 0:04 & $0: 27$ & $0: 05$ & 0:04 & 0:04 & $0: 03$ & $0: 03$ & 0:03 \\
\hline 5 & 0:07 & 0:09 & 0:07 & 0:07 & $0: 05$ & $0: 05$ & $0: 05$ & $0: 05$ & 0:04 & $0: 03$ & $0: 03$ & 0:03 \\
\hline
\end{tabular}

Flood caused by dam break

Flood caused by direct runoff 


\subsubsection{Available Warning Time}

Available warning time was calculated based on two conditions, the first was available warning time based on the flood peak discharge, as shown in Table 15. The second condition was available warning time that was calculated based on the time the critical elevation to be reached in Nasiri residential area. With the initial assumption that the storage was in full condition, the available warning time on the flood event caused by natural dam break then could be calculated by adding the break time with the flood peak time and its travel time. Table 15 is the available warning time that was based on the flood peak discharge.

On the other hand, Table 6 was the available warning time when it's calculated based on the time the critical elevation to be reached in Nasiri residential area, which was by adding the break time with the time the critical elevation to be reached in Nasiri residential area.

Table 15. Available warning time based on peak discharge

\begin{tabular}{|c|c|c|c|c|c|c|c|c|c|c|c|c|}
\hline \multirow{3}{*}{$\begin{array}{l}\text { Watershed } \\
\text { elevation } \\
\text { (m) }\end{array}$} & \multicolumn{12}{|c|}{ Available Warning Time (Hour: Minute) } \\
\hline & \multicolumn{4}{|c|}{ Sub-watershed 3} & \multicolumn{4}{|c|}{ Sub-watershed 4} & \multicolumn{4}{|c|}{ Sub-watershed 5} \\
\hline & $\begin{array}{l}\text { Rain } \\
\text { Event }\end{array}$ & $\begin{array}{l}2 \\
\text { years }\end{array}$ & $\begin{array}{l}3 \\
\text { years }\end{array}$ & $\begin{array}{l}5 \\
\text { years }\end{array}$ & $\begin{array}{l}\text { Rain } \\
\text { Event }\end{array}$ & $\begin{array}{l}2 \\
\text { years }\end{array}$ & $\begin{array}{l}3 \\
\text { years }\end{array}$ & $\begin{array}{l}5 \\
\text { years }\end{array}$ & $\begin{array}{l}\text { Rain } \\
\text { Event }\end{array}$ & $\begin{array}{l}2 \\
\text { years }\end{array}$ & $\begin{array}{l}3 \\
\text { years }\end{array}$ & $\begin{array}{l}5 \\
\text { years }\end{array}$ \\
\hline 12.5 & $2: 49$ & $2: 02$ & $1: 57$ & $2: 50$ & $2: 27$ & $2: 23$ & $2: 17$ & $2: 28$ & $1: 48$ & $1: 59$ & $1: 54$ & $1: 49$ \\
\hline 10 & $2: 49$ & $2: 45$ & $2: 40$ & $2: 51$ & $2: 33$ & $2: 22$ & $2: 36$ & $2: 33$ & 2:04 & $2: 15$ & $2: 19$ & 2:09 \\
\hline 7.5 & $2: 49$ & $2: 55$ & $2: 52$ & $2: 50$ & $2: 38$ & $2: 51$ & $2: 46$ & $2: 40$ & $2: 54$ & $2: 59$ & $2: 56$ & $2: 54$ \\
\hline 5 & $2: 49$ & $2: 55$ & $2: 52$ & $2: 50$ & $2: 34$ & $2: 46$ & $2: 40$ & $2: 35$ & $2: 54$ & $2: 58$ & $2: 57$ & $2: 54$ \\
\hline
\end{tabular}

Flood caused by dam break

Flood caused by direct runoff

Table 16. Available warning time based on whether the critical elevation on Nasiri residential area is reached or not

\begin{tabular}{|c|c|c|c|c|c|c|c|c|c|c|c|c|}
\hline \multirow{3}{*}{$\begin{array}{l}\text { Watershed } \\
\text { elevation } \\
\text { (m) }\end{array}$} & \multicolumn{12}{|c|}{ Available Warning Time (Hour: Minute) } \\
\hline & \multicolumn{4}{|c|}{ Sub-watershed 3} & \multicolumn{4}{|c|}{ Sub-watershed 4} & \multicolumn{4}{|c|}{ Sub-watershed 5} \\
\hline & $\begin{array}{l}\text { Rain } \\
\text { Event }\end{array}$ & $\begin{array}{l}2 \\
\text { years }\end{array}$ & $\begin{array}{l}3 \\
\text { years }\end{array}$ & $\begin{array}{l}5 \\
\text { years }\end{array}$ & $\begin{array}{l}\text { Rain } \\
\text { Event }\end{array}$ & $\begin{array}{l}2 \\
\text { years }\end{array}$ & $\begin{array}{l}3 \\
\text { years }\end{array}$ & $\begin{array}{l}5 \\
\text { years }\end{array}$ & $\begin{array}{l}\text { Rain } \\
\text { Event }\end{array}$ & $\begin{array}{l}2 \\
\text { years }\end{array}$ & $\begin{array}{l}3 \\
\text { years }\end{array}$ & $\begin{array}{l}5 \\
\text { years }\end{array}$ \\
\hline 12.5 & & & & & $1: 46$ & $2: 05$ & $1: 56$ & $1: 49$ & $1: 33$ & $1: 48$ & $1: 41$ & $1: 35$ \\
\hline 10 & & & & & $1: 53$ & & $2: 12$ & $1: 56$ & $1: 52$ & & 2:03 & $1: 54$ \\
\hline 7.5 & & & & & 2:05 & & & $2: 10$ & $2: 13$ & & & $2: 23$ \\
\hline 5 & & & & & $2: 12$ & & & $2: 19$ & $2: 17$ & & & $2: 24$ \\
\hline
\end{tabular}

Critical elevation not exceeded

Critical elevation exceeded

\section{CONCLUSIONS AND SUGGESTIONS}

\subsection{Conclusions}

The conclusions that could be taken from this research are as follows.

a) The time duration of storage filling time was on time range of 2 hours 26 minutes to 5 minutes.

b) Discharges of a flood caused by a natural dam in the Nasiri residential area have value ranged from 49.51 to $164.53 \mathrm{~m}^{3} / \mathrm{s}$.

c) With natural dam elevation of $5 \mathrm{~m}$, the presence of natural dam did not affect the flood peak discharge occurred. The flood peak discharge was more influenced by the direct runoff.

d) Available Warning Time was generally less than 3 hours, with a time range of 1 hour 48 minutes to 2 hours 58 minutes, if based on its peak discharge; and ranged from 1 hour 33 minutes to 2 hours 24 minutes if based on the time-critical elevation is reached on the Nasiri residential area. e) The flood threat caused by river water overflowing through levee peak elevation in Nasiri did not occur on all the scenario of a natural dam break. However, based on the conducted studies, if the river water elevation exceeds the existing gabion peak elevation $( \pm 1 \mathrm{~m}$ from river base $)$, it is tended to trigger the levee on the right and left the side of the river stream to break.

\subsection{Suggestions}

The followings are some suggestions that may useful for the next research.

a) The geological study is needed to learn the landslide potency that could possibly occur at alongside the Nasiri River.

b) This research used the HEC-RAS software only for the flood routing because the dam break was a result of the HEC-HMS software simulation. Running dam break would be more detailed if it is directly modeled with HEC-RAS software. 
c) A reliable early warning system device is absolutely necessary for the study location, as a mitigation/countermeasure effort for the fairly short available warning time value.

\section{REFERENCES}

Anon., 1991. User's Manual Boss Dambrk, USA: Boss Corporation.

Chandrabose, G. \& Nair B, T., 2014. Dam Break Analysis using HECRAS with DEM Generated Geometry. International Journal of Scientific \& Engineering Research, pp. 313-319.

Chow, V. T., 1997. Open Channel Hydraulics. Edisi keempat ed. Jakarta: Erlangga.

Musthofa, A., 2015. Simulasi Banjir Bandang Untuk Sistem Peringatan Dini dan Peta Bahaya [Flash Flood Simulation for Early Warning System and Hazard Map], Yogyakarta: Master Thesis, Faculty of Engineering, Universitas Gadjah Mada.

Primahessa, A., 2017. Analisa Karakteristik Hujan Penyebab Banjir pada Sistem Peringatan Dini di Sungai dengan Kemiringan Curam [Analysis of
Rainfall Characteristics for Early Warning System in Steep Slope Channel], Yogyakarta: Master Thesis, Faculty of Engineering, Universitas Gadjah Mada.

Rachmadan, L., Juwono, P. T. \& Asmaranto, R., 2014. Analisa Keruntuhan Bendungan Alam Way Ela Dengan Menggunakan Program Zhong Xing Hy21 [Dam Breach Analysis in Way Ela Case using Zhong Xing Hy21 Program], Malang: Universitas Brawijaya.

Rahardjo, A. P., Sujono, J., Jayadi, R. \& Legono, D., 2009. Simulation of a Dam Break Triggered Flood, the Case of Situ Gintung Disaster on March 27, 2009. Yogyakarta, pp. 271-283.

Sanjay, L. D. \& Ravindra, A. O., 2012. Dynamic Flood Routing And Unsteady Flow Modelling: A Case Study Of Upper Krishna River. International Journal of Advanced Engineering Technology, III(III), pp. 55-59.

Styawan, A. P., 2017. Studi Kejadian dan Potensi Banjir Bandang oleh Keruntuhan Dam Alam di Nasiri [Case Study and Potential Flash Flood caused by Dam Breach in Nasiri Village], Yogyakarta: Master Thesis, Faculty of Engineering, Universitas Gadjah Mada. 